\title{
SUCCESS FACTORS OF ACCOUNTING INFORMATION SYSTEM IN PT. KUNCIMAS NIAGATAMA BANYUWANGI
}

\author{
Nofita Ambarwati ${ }^{1}$ \\ Muhammad Firdaus ${ }^{2}$, \\ Nanda Widaninggar ${ }^{3}$ \\ Higher Education of Economic Mandala \\ E-mail: nanwiedha@stie-mandala.ac.id
}

\begin{abstract}
This study aims to analyze the factors that influence the success of the accounting information system at PT. Kuncimas Niagatama Banyuwangi. The success of accounting information systems is influenced by Human Behavior in Organizations, Management Support, Motivation and Training, Data Processing in the System, and Management and Implementation Process. This study used the primary data by total sample of thirty-five employees and used the purposive sampling technique. The quality of the questionnaire was tested using the validity test and reliability test. Data analysis used multiple regression analysis, which includes the classic assumption test, $t$ test and the coefficient of determination The results showed that Human Behavior in Organizations, Motivation and Training, Management and Implementation Process significantly influence the Success of AIS Implementation. Only Management Support variable and Data Processing in the System have no significant effect on the Success of AIS Implementation.
\end{abstract}

Keywords: Accounting Information System, Human Behavior, Motivation and Training, Management and Implementation Process

\section{INTRODUCTION}

By the acceleration of science and technology in the era of globalization, with the growth rate of the world economy impacts on the business development, including increasing the activities carried out by government offices (agencies), organizations or business entities (companies). The general condition of the companies was the increasing need for management of financial administration, equipment, human resources and aspects of planning, also control and supervision. Accounting Information System (AIS) was needed for planning and decision making in the context of business to achieve the company's strategic goals (Hall, 2007): 18).

Information technology in companies should be able to become a kind of "way of life" as has happened in developed countries, no longer just creating efficiency or making business processes more automatic, but already at a more level to improve performance and increase 
customer satisfaction. In the company's business processes, that is when the complexity has been felt by corporate entities. This is characterized by the number of workers that must be managed, the number of branch offices or just storage warehouses scattered in various locations (Widaninggar, 2013): 315).

The implementation of Accounting Information System in PT. Kuncimas Niagatama Banyuwangi aims to support the responsibility of management of the company because the main activity of management was the responsibility for informing the organization and use of organizing resources in achieving the goals of the organization. In addition, to support the company's day-to-day operations. Information systems help operational personnel to work more effectively and efficiently (Hall, 2007). But in terms of the phenomena, there were still some problems that arise in PT. Kuncimas Niagatama Banyuwangi which was related to the use of Accounting Information System. The human behavior in organizations should be consciously coordinated in social units, consisting of two or more people who function relatively sustainably to achieve common goals (Robbins \& Timothy, 2007). In fact there was still a gap in the delivery of information seen from the lack of good the process of interaction and communication between units within the company so that it affected work productivity and cause the obstacles in carrying out the task.

The obstacle in the form of employee negligence was in adjusting the physical stock of goods in the warehouse unit of PT. Kuncimas Niagatama Banyuwangi with the existing stock of goods in the system, so that when the retail market asked for a certain amount of inventory it turns out that the physical stock of goods was insufficient even though the system contains sufficient stock. The difference between the physical stock and the stock system was an obstacle in the distribution of goods from PT. Kuncimas Niagatama Banyuwangi as a distributor to the retail market. This late distribution occurred because PT. Kuncimas Niagatama Banyuwangi must first adjusted the physical stock of the warehouse by ordering physical stock of goods from the head office, namely PT. SOLAR WINGS. That caused the retail market to be late in receiving goods that had been ordered. The other impact that occurred was the ineffectiveness of operational activities at PT. Kuncimas Niagatama Banyuwangi. In addition, motivation and training conducted by PT. The Kuncimas Niagatama Banyuwangi was carried out only when updating the accounting information system without any regular training that should be held to increase employee participation in the process of developing information systems that can help them work and possibly keep their jobs (Gondodiyoto, 2007): 162. The impact of irregular training at PT. Kuncimas Niagatama Banyuwangi causes employees to be less nimble in working so that the existence of an Accounting Information System reduces work effectiveness.

This study analyzed whether Human Behavior in the Organization, Management Support, Motivation and Training, Data Processing in the System, Management and Implementation Processes affect the existence of an Accounting Information System in PT. Kuncimas Niagatama Banyuwangi.

\section{RESEARCH METHODS}

\section{Research Object}

This research was conducted at PT. Kuncimas Niagatama Banyuwangi which was engaged in the distribution of consumer products. Through principle or main suppliers of PT. Wings Surya in the form of food, soap, drinks, skin care and personal care. The company is located at Jl. Yos Sudarso No. 111-A, Neighborhood Sukowidi, Klatak, Kec. Banyuwangi, Banyuwangi Regency, East Java. 


\section{Population and Sample}

The population in this study were the employees who worked at PT. Kuncimas Niagatama Banyuwangi in the amount of 200 employees in the year of 2019. The sampling technique used in this study was purposive sampling (Sugiyono, 2017). The criteria to be sampled include:

1. Status of active and permanent employees,

2. Employees who had the work experience in this company which was more than one year,

3. Employees who used the Information System, included the administration staffs, warehouse staffs, stockers, managements, cashiers, warehouse managements and Information Technology staffs.

\section{Identification of Variabel}

Variables of this research could be identified as follows:

\section{Human Behavior in Organizations}

Organizations were consciously coordinated social units consisting of two or more people who function relatively sustainably to achieve a common goal (Robbins \& Timothy, 2007). Organizations were seen from the process of interaction and communication between people or units within an organization, while patterns of behavior saw and learned the patterns of behavior of individuals and groups that drive the process of interaction within the organization (Ardana \& Lukman, 2016). Human behavior in organization could be proxied by the Involvement of the Users. (Utama, 2014), (Sahusilawane, 2014), (Hidayati, 2015), and (Purwa, 2016) found that the Involvement of the Users had a significant impact to the success of Accounting Information System. It was different with the research conducted by (Wulandari, 2018), which found that the Involvement of Users had no significant impact to the success of Accounting Information System.

\section{Management Support}

Management support existed when all levels of management agree on an information system project, making the project positively perceived by users and information service technical staff. This support could be realized in the form of active participation/support, the time and energy devoted to the project, sufficient financial support, and various organizational changes that are needed (Gondodiyoto, 2007): 162). (Sahusilawane, 2014), (Hidayati, 2015), and (Purwa, 2016) found that Management Support had a significant impact to the success of Accounting Information System. In the other side, (Utama, 2014) and (Wulandari, 2018) found that the Management Support had no significant impact to the success of Accounting Information System.

\section{Motivation and Training}

Motivation and training of users who get adequate motivation and training will be able to increase participation in the process of developing information systems and will eliminate their resistance to new systems that they think may be a threat to their interests, users must understand clearly how the new system can help them work and might keep their jobs (Gondodiyoto, 2007): 163). This theory support the research conducted by (Hirschheim, 1985), (Nelson \& Cheney, 1987). (Huff \& Munro, 1985) in (Soegiharto, 2001) which found that the capability of AIS' personnel had an impact on design quality and the performance of Information System. Human Resource competency which could be achieved by continuous training were abilities had by a person related to the knowledge, capability, and personality characteristics that significantly affect the performance to achieve the goals set up. (Purwa, 2016) found that Training had a significant impact to the success of Accounting Information System. In the other side (Wulandari, 2018) said that Motivation and Training had no 
significant impact to the success of Accounting Information System.

\section{Data Processing}

Data processing is the activity of processing data manipulating or processing data to be used as information. Data processing activities include arithmetic activities (summing, subtracting, multiplying, dividing) driving, duplicating, comparing, classifying, summarizing and presenting the results of processed data in various forms such as graphs, tables and reports (Ardana \& Lukman, 2016): 23).

\section{Management and Implementation Process}

Management is the process of achieving predetermined goals through activities carried out by others (George \& Leslie, 2000), 2000). The implementation phase is the period of time during which the work system is generated and placed in operation. Implementation begins when the information systems steering committee receives detailed specifications produced during system design (Sutabri, 2015). Many researchers conducted the research of user involvement. The involvement influences the key variables such as system quality, user satisfaction and system use (Ives \& Olson, 1994); (Hirschheim, 1985); (Nelson \& Cheney, 1987). The involvement of the user in the system development process had a positive influence on the satisfaction related with the Computerize Based Information System (CBIS). Research on the implementation of computer-based information systems has shown that there is no single explanation of what factors can significantly encourage or be the cause of success/failure of a system implementation. However, research has found that the results of implementation are broadly determined by several factors such as human behavior in organizations, management support, motivation and training, data processing in the system, management and implementation process (Gondodiyoto, 2007).

\section{Data Analysis}

\section{Multiple Linear Regression}

The analytical tool used in this study was multiple linear regression. Multiple linear regression analysis was used to determine the linear effect of two or more independent variables $(\mathrm{X} 1, \mathrm{X} 2, \ldots \mathrm{Xn})$ on the dependent variable (Y) (Firdaus, 2019). The formulation of multiple regression equations in this study becomes as follows:

$Y=a+b_{1} X_{1}+b_{2} X_{2}+b_{3} X_{3}+b_{4} X_{4}+b_{5} X_{5}+e$

Keterangan:

Y : The successful implementation accounting information system (Y)

A : Constants

B : Regression coefficient

X1 : Human Behavior in Organizations

X2 : Management Support

X3 : Motivation and Training

X4 : Data Processing in the System

X5 : Management and Implementation Process

E : error

\section{Classical Assumption Test}

Prior to hypothesis testing, it is necessary to examine whether there is any violation of classical assumptions. According to (Gujarati, 2004), classical assumption test is done so that the regression equation is built is BLUE. The assumptions test used normality test, multicollinearity, heteroscedasticity test and autocorrelation test.

\section{Coefficient of Determination}

The coefficient of determination $\left(\mathrm{R}^{2}\right)$ basically measures how far the model's ability to explain the variation of the dependent variable. The value of the coefficient of determination is between zero and one. A small value means the ability of independent variables to explain the dependent variable is limited. Values that are close to one independent variable provide almost all the information needed to predict the dependent variable (Supranto, 2005). 


\section{Hypothesis testing}

Hypothesis testing is done to determine the effect of the independent variable on the dependent variable statistically. This research used the $\mathrm{t}$-test $(\mathrm{t}$ test). The test is performed to determine whether each independent variable individually significant effect on the dependent variable (Firdaus, 2019).

\section{RESULT AND DISCUSSION}

\section{Validity Test}

Validity test was used to determine the appropriateness of items in a list of questions in defining a variable. The results of $r$ count we compare with $r$ table where $\mathrm{df}$ $=\mathrm{n}-2$ with sig 5\%. If $\mathrm{r}$ table $<\mathrm{r}$ count is valid (Sujarweni, 2015). The validity test results in this study are as follows:

Table 1. Questionnaire Validity Test Results

\begin{tabular}{|l|c|c|c|}
\hline \multirow{2}{*}{\multicolumn{1}{|c|}{ Variables }} & \multicolumn{2}{c|}{ Validity Test } & \multirow{2}{*}{ Information } \\
\cline { 2 - 3 } & R Calculate & R Table & \\
\hline Human Behavior in Organizations $\left(\mathrm{X}_{1}\right)$ & 0,503 & 0,334 & Valid \\
\hline Management Support $\left(\mathrm{X}_{2}\right)$ & 0,402 & 0,334 & Valid \\
\hline Motivation and Training $\left(\mathrm{X}_{3}\right)$ & 0,404 & 0,334 & Valid \\
\hline Data Processing in the System $\left(\mathrm{X}_{4}\right)$ & 0,776 & 0,334 & Valid \\
\hline Management and Implementation Process $\left(\mathrm{X}_{5}\right)$ & 0,389 & 0,334 & Valid \\
\hline Successful Implementation of AIS $(\mathrm{Y})$ & 0,383 & 0,334 & Valid \\
\hline
\end{tabular}

Based on Table 1 above, it appears that all question items for both Human Behavior in Organizations $\left(\mathrm{X}_{1}\right)$, Management Support $\left(\mathrm{X}_{2}\right)$, Motivation and Training $\left(\mathrm{X}_{3}\right)$, Data Processing in the System $\left(\mathrm{X}_{4}\right), \quad$ Management and Implementation Process $\left(\mathrm{X}_{5}\right)$, and Successful Implementation of AIS (Y) variables were all valid.

\section{Reliability Test}

Reliability test used in this study was to use the Cronbach Alpha coefficient. If the Cronbach Alpha value $>0.70$ in a variable, the instrument measurement reliability level was getting better. The Reliability Test Results in this study are as follows:

Table 2. Questionnaire Reliability Test Results

\begin{tabular}{|l|c|c|c|}
\hline \multicolumn{1}{|c|}{ Variable } & $\begin{array}{c}\text { Number of } \\
\text { Questions }\end{array}$ & $\begin{array}{c}\text { Cronbach } \\
\text { Alpha }\end{array}$ & Information \\
\hline Human Behavior in Organizations $\left(\mathrm{X}_{1}\right)$ & 4 & 0,770 & Reliable \\
\hline Management Support $\left(\mathrm{X}_{2}\right)$ & 4 & 0,770 & Reliable \\
\hline Motivation and Training $\left(\mathrm{X}_{3}\right)$ & 5 & 0,770 & Reliable \\
\hline Data Processing in the System $\left(\mathrm{X}_{4}\right)$ & 5 & 0,770 & Reliable \\
\hline Management and Implementation Process $\left(\mathrm{X}_{5}\right)$ & 4 & 0,770 & Reliable \\
\hline Successful Implementation of AIS $(\mathrm{Y})$ & 5 & 0,770 & Reliable \\
\hline
\end{tabular}

Based on table 2 above, it appears that all question items for both Human Behavior in Organizations $\left(\mathrm{X}_{1}\right)$, Management Support $\left(\mathrm{X}_{2}\right)$, Motivation and Training $\left(\mathrm{X}_{3}\right)$, Data Processing in the System $\left(\mathrm{X}_{4}\right), \quad$ Management and Implementation Process $\left(\mathrm{X}_{5}\right)$, and
Successful Implementation of AIS (Y) variables were all reliable.

\section{Classical Assumption Test}

The classical assumption tests conducted in this study were the normality test, the multicollinearity test and the heteroscedasticity test. 


\section{Normality test}

To find out whether the data were normally distributed or not in this study was carried out using the Normal P-P plot. The results of the normality test in this study are as follows:

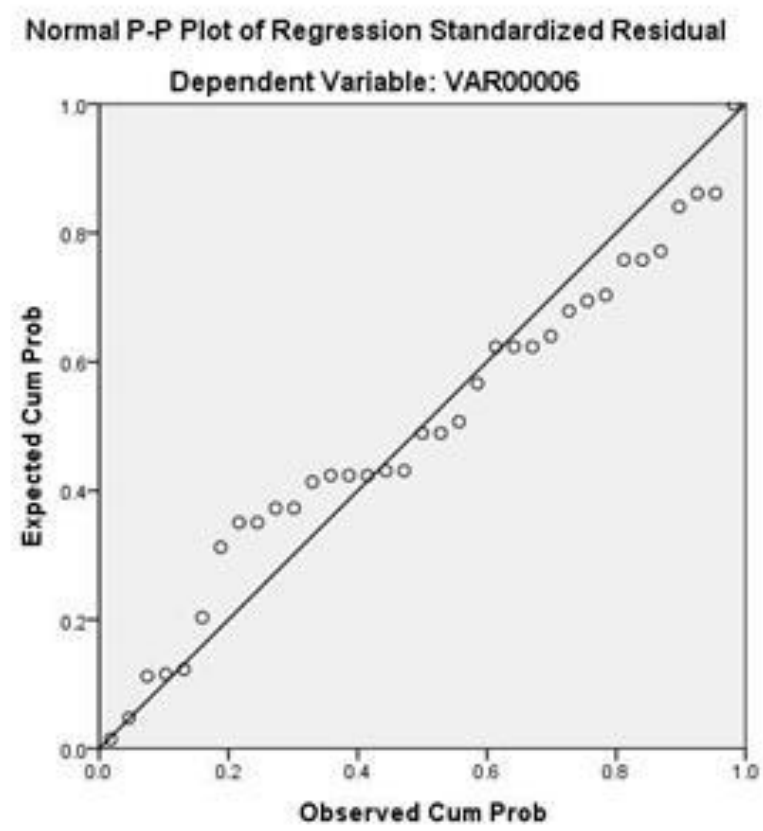

Picture 1: Normality Test Results

Based on the normal plot graph, visible points spread around the diagonal line and spread not far from the diagonal line. This shows that the pattern graph was normally distributed, then the regression model meets the normality assumption.

\section{Multicollinearity}

To determine whether there was a correlation between the dependent variables in this study, the multicollinearity test was used. If tolerance value $<0.01$ or Variance Inflation Factor $>10$, there will be multicollinearity. But if the opposite does not occur multicollinearity (Ghozali, 2013). The results of the multicollinertias test are as follows:

Table 3. Multicollinearity Test Results

\begin{tabular}{|c|c|c|c|c|c|c|c|c|}
\hline \multicolumn{9}{|c|}{ Coefficients $^{a}$} \\
\hline \multirow{2}{*}{\multicolumn{2}{|c|}{ Model }} & \multicolumn{2}{|c|}{ Unstandardized Coefficients } & \multirow{2}{*}{$\begin{array}{c}\begin{array}{c}\text { Standardized } \\
\text { Coefficients }\end{array} \\
\text { Beta }\end{array}$} & \multirow[b]{2}{*}{$t$} & \multirow[b]{2}{*}{ Sig. } & \multicolumn{2}{|c|}{ Collinearity Statistics } \\
\hline & & B & Std. Error & & & & Tolerance & VIF \\
\hline \multirow[t]{6}{*}{1} & (Constant) & 1.819 & 1.807 & & 1.006 & .323 & & \\
\hline & VAR00001 & .236 & .106 & .329 & 2.229 & .034 & .294 & 3.403 \\
\hline & VAR00002 & .012 & .081 & .019 & .154 & .879 & .430 & 2.324 \\
\hline & VAR00003 & .190 & .079 & .231 & 2.394 & .023 & .689 & 1.452 \\
\hline & VAR00004 & .095 & .062 & .151 & 1.524 & .138 & .648 & 1.543 \\
\hline & VAR00005 & .412 & .155 & .365 & 2.657 & .013 & .338 & 2.954 \\
\hline
\end{tabular}

a. Dependent Variable: VAR00006

Based on Table 3 above, it appears that all variables, i.e. Human Behavior in Organizations $\left(\mathrm{X}_{1}\right)$, Management Support $\left(\mathrm{X}_{2}\right)$, Motivation and Training $\left(\mathrm{X}_{3}\right)$, Data Processing in the System $\left(\mathrm{X}_{4}\right)$, and Management and Implementation Process
$\left(\mathrm{X}_{5}\right)$ do not indicate the presence of Multicollinearity.

\section{Heteroskedasticity}

A good regression model was one that does not occur heteroscedasticity 
(homoscedasticity). To find out the presence or absence of heteroscedasticity in this study the Gleyser Test was used. The Gleyser test was performed by way of regressing the independent variable with its absolute residual value (abs_res). If the significant value was between the independent variable and the absolute residual value $>0.05$ then there was no heteroscedasticity problem. Gleyser test results are shown in the following table.

Table 4: Heteroscedasticity Test Results by the Glesyer Method

Coefficients $^{a}$

\begin{tabular}{|c|c|c|c|c|c|c|}
\hline \multirow{2}{*}{\multicolumn{2}{|c|}{ Model }} & \multicolumn{2}{|c|}{ Unstandardized Coefficients } & \multirow{2}{*}{$\begin{array}{c}\text { Standardized } \\
\text { Coefficients }\end{array}$} & \multirow[b]{2}{*}{$t$} & \multirow[b]{2}{*}{ Sig. } \\
\hline & & $\mathrm{B}$ & Std. Error & & & \\
\hline \multirow[t]{6}{*}{1} & (Constant) & .602 & 1.123 & & .536 & .596 \\
\hline & VAR00001 & -.030 & .066 & -.137 & -.450 & .656 \\
\hline & VAR00002 & -.101 & .050 & -.505 & -2.011 & .054 \\
\hline & VAR00003 & .005 & .049 & .018 & .092 & .927 \\
\hline & VAR00004 & -.013 & .039 & -.067 & -.326 & .747 \\
\hline & VAR00005 & .118 & .096 & .345 & 1.220 & .232 \\
\hline
\end{tabular}

a. Dependent Variable: res2

From Table 4 above it appears that the regression model of the regression model in this research does not show heteroscedasticity.

\section{Multiple Linear Regression}

The equation of Implementation Success Equation (Y) was built by five variables namely Human Behavior in Organizations $\left(\mathrm{X}_{1}\right)$, Management Support $\left(\mathrm{X}_{2}\right)$, Motivation and Training $\left(\mathrm{X}_{3}\right)$, Data
Processing in the System $\left(\mathrm{X}_{4}\right)$, Management and Implementation Process $\left(\mathrm{X}_{5}\right)$ (see Table 5). The equation has an $\mathrm{R}^{2}$ value of 0.815 . This means that the change in the five variables was able to explain $81.50 \%$ of the variation of the independent variable, while the rest $(8.50 \%)$ is influenced by other variables outside the equation.

Table 5. Linear Regression Results Equation to the Successful of AIS Implementation

\begin{tabular}{lrrrc}
\hline \multicolumn{1}{c}{ Variable } & $\begin{array}{c}\text { Estimated } \\
\text { Parameters }\end{array}$ & $\mathbf{t}_{\text {calculate }}$ & Sig. & Information \\
\hline Intercept & 1.819 & 1.006 & 0.323 & \\
Human Behavior in Organizations $\left(\mathrm{X}_{1}\right)$ & 0.236 & 2.229 & 0.034 & Significant \\
Management Support $\left(\mathrm{X}_{2}\right)$ & 0.012 & 0.154 & 0.879 & Not Significant \\
Motivation and Training $\left(\mathrm{X}_{3}\right)$ & 0.190 & 2.394 & 0.023 & Significant \\
& & & & \\
Data Processing in the System $\left(\mathrm{X}_{4}\right)$ & 0.095 & 1.524 & 0.138 & Not Significant \\
Management and Implementation Process $\left(\mathrm{X}_{5}\right)$ & 0.412 & 2.657 & 0.013 & Significant \\
\hline $\mathrm{F}_{\text {hitung }}$ & & 25.492 & 0.000 & Significant \\
$\mathrm{R}^{2}$ & & 0.815 & & \\
\hline
\end{tabular}

By the t-test on each variable shows that Human Behavior in Organizations $\left(\mathrm{X}_{1}\right)$, Motivation and Training $\left(\mathrm{X}_{3}\right)$, Management and Implementation Process $\left(\mathrm{X}_{5}\right)$ significantly influence the Success of
AIS Implementation (Y). Only management support variables $\left(\mathrm{X}_{2}\right)$ and Data Processing in the System $\left(\mathrm{X}_{4}\right)$ have no significant effect on the Success of AIS Implementation (Y). 


\section{INTERPRETATION}

This discussion aims to determine the effect of Human Behavior in Organizations, Management Support, Motivation and Training, Data Processing in the System, Management and Implementation Process on the successful Implementation of Accounting Information Systems at PT. Kuncimas Niagatama Banyuwangi.

\section{Impact of Human Behavior in Organizations on the Success Factors of Accounting Information System Implementation}

Concerning to the result of the analysis in the influence of Human Behavior in Organizations on the successful Implementation of Accounting Information Systems that was Human Behavior in organizations had a positive relation and significantly influences the successful Implementation of Accounting Information Systems. So, for the hypothesis which states that Human Behavior in Organizations influence the Successful Implementation of Accounting Information Systems was accepted. Therefore, Human Behavior in Organizations that carry out special functions with a good system can achieve the objectives of the success of the Accounting Information System. This found was in line with the research of (Utama, 2014), (Sahusilawane, 2014), (Hidayati, 2015), and (Purwa, 2016) in the proxy of Involvement of the Users in the system.

\section{Impact of Management Support on the Success Factors of Accounting Information System Implementation}

According to the analysis of the effect of Management Support on the successful Implementation of Information Systems, Management Support had a positive relation but did not have a significant effect on the success of the Implementation of Accounting Information Systems. So, for the hypothesis that
Management Support affects the Successful Implementation of Accounting Information Systems is accepted. Therefore, Management Support that runs management pays high attention to the performance of information systems on the success of Accounting Information Systems.

As the result of the variable test that the Management Support variable did not have a significant effect, the results of research of (Utama, 2014) and (Wulandari, 2018) show that the Planning Process, Management Support, The User Role in the Implementation Process, Motivation and Training had no significant effect on the successful of Implementation of Accounting Information Systems. Whereas the Management variables and the Implementation Process significantly influence the Successful Implementation of Accounting Information Systems. So, the company can maintain the Management and Implementation that has been arranged in detail and mature so that the objectives in achieving the success of the Information System can be achieved. This result in line with (Sahusilawane, 2014), (Hidayati, 2015), and (Purwa, 2016) which found that Management Support had a significant impact to the success of Accounting Information System.

\section{Impact of Motivation and Training on the Success Factors of Accounting Information System Implementation}

Based on the analysis of the influence of Motivation and Training on the successful Implementation of Accounting Information Systems showed that Motivation and Training had a positive relation and significantly influence on the success of the Implementation of Accounting Information Systems. So, for the hypothesis which states that Motivation and Training affect the successful Implementation of Accounting Information Systems was accepted. Therefore, Motivation and Training provided by the 
company on a regular basis for the vision, mission and goals of the company can achieve the objectives of the success of the Accounting Information System.

As the result of the analysis, the Motivation and Training variables had a significant effect and seen from the questionnaire that the variables of Motivation and Training were consistent with the results of other studies, (Purwa, 2016), found that Training had a significant impact to the success of Accounting Information System. Research of (Wulandari, 2018) showed that the variables of the Planning Process, Management Support, the Role of Users in the Process of Implementation, Motivation and Training had no significant effect on the successful Implementation of Accounting Information Systems. By that, it could be seen that variables in the term and condition had a different effect on the successful Implementation of Accounting Information Systems.

\section{Impact of Data Processing in the System on the Success Factors of Accounting Information System Implementation}

According to the analysis of the impact of the Data Processing in the system on the successful Implementation of Accounting Information Systems, Data Processing in the system had a positive relation but did not have a significant effect on the success of the Implementation of Accounting Information Systems. So, for the hypothesis which states that Data Processing in the system affects the successful Implementation of Accounting Information Systems was accepted. Therefore, Data Processing which was considered in low quality and inaccurate data could be a serious problem in processing data on the success of the Accounting Information System. As the result of the test variables, the data processing variable in the system had no significant effect.
5. Impact of Management and Implementation Process on the Success Factors of Accounting Information Systems Implementation

By the analysis of Management's influence and Implementation Process on the successful Implementation of Accounting Information Systems, Management and the Implementation Process had a positive relation and had a significant effect on the successful Implementation of Accounting Information Systems. So, for the hypothesis which states that Management and the Implementation Process influences the successful Implementation of Accounting Information Systems was accepted. Therefore, Management and Implementation Processes that cost the development of information systems are excessive so that beyond the budget can achieve the objectives of the success of the Accounting Information System. As the test of variables showed that the Management and the Implementation Process had a significant effect, and the results of (Wulandari, 2018) showed that the management variables and the implementation process had a significant effect on the successful implementation of the Accounting Information System.

\section{CONCLUSION}

The results of the study can be concluded that the Human Behavior in Organizations, Motivation and Training, Management and Implementation Process impact the Successful Implementation of Accounting Information Systems in PT. Kuncimas Niagatama Banyuwangi, while the Management Support and Data Processing in the System indicated that there was no significant effect on the Success Factors of the Accounting Information System Implementation.

\section{IMPLICATION}

Based on the conclusion above there were three variables that influence the 
success factors of the Implementation of Accounting Information Systems. First, the Human Behavior variable in Organizations, which was significantly influences the successful Implementation of Accounting Information Systems, so that the companies must further enhance the task of Human Resource who work with the system must be clearly defined, information systems in line with organizational goals and information systems must be built to meet the desired task formulation. Second, Motivation and Training Variables significantly influence the success factors of the Implementation of Accounting Information Systems. In the company's Motivation and Training were very necessary because motivation was very important to be the driving activities for workers to further increase company productivity. This encouragement aims to encourage employees so that they were excited and could achieve the desired results. Then, the third were Management and the Implementation Process which were significantly influence the successful Implementation of Accounting Information Systems, so the company could maintain and improve a system.

\section{REFERENCES}

Ardana, I. C., \& Lukman, H. (2016). Sistem Informasi Akuntansi. Jakarta: Mitra Wacana Media.

Firdaus, M. (2019). Ekonometrika Suatu Pendekatan Aplikatif. Jakarta: Bumi Aksara.

George, R. T., \& Leslie, W. R. (2000). Dasar-Dasar Manajemen. Jakarta: PT. Bumi Aksara.

Ghozali, I. (2013). Aplikasi Analisis Multivaraite dengan SPSS. Semarang: Badan Penerbit UNDIP.

Gondodiyoto, S. (2007). Audit Sistem Informasi. Jakarta: Mitra Wacana Media.

Gujarati, D. (2004). Basic Econometrics. New York: McGraw-Hill, Inc. Hall, J. A. (2007). Sistem Informasi
Akuntansi Buku ke-1, Terjemahan Jusuf, A. A. (1st ed.). Jakarta: Salemba Empat.

Hidayati, A. (2015). Faktor-faktor yang Mempengaruhi Kinerja Sistem Informasi Akuntansi Pada Kementerian Kelautan dan Perikanan $R I$. Universitas Gunadarma.

Hirschheim. (1985). Information Systems Epistemologi: An historical perspective. In Research Methods in Information System (pp. 13-35).

Retrieved from https://ifipwg82.org/sites/ifipwg82.org /files/ Hirschheim_0.pdf. Accessed on March 21, 2020

Huff, S. L., \& Munro, M. C. (1985). Information Technology Assessment and Adoption: A Field Study. MIS Quarterly, 9(4), 229-309. Retrieved from https://misq.org/informationtechnology-assessment-and-adoptiona-field-study.html. Accessed on March 21, 2020

Ives, \& Olson. (1994). The Relationship Btween User Participation and User Satisfaction: An Investigation of Four Contingency Factors. MIS Quarterly, (December). Retrieved from https://www.academia.edu/19852102/ The Relationship between User Participation and User Satisfaction An Investigation of Four Contingency Factors. Accessed on July 8, 2019

Nelson, R. R., \& Cheney, P. H. (1987). Training and Users : An Exploratory Study. MIS Quarterly, 547-559.

Retrieved from https://pdfs.semanticscholar.org/1bf9/ 77ca584b1e07309aa9956e115915da50 8a30.pdf. Accessed on March 21, 2020

Purwa, W. A. (2016). Analisis Faktorfaktor yang Mempengaruhi Kinerja Sistem Informasi Akuntansi. Jurnal Akuntansi.

Robbins, S. R., \& Timothy, A. J. (2007). Organization Behavior. Ney Jersey: Pearson International.

Sahusilawane, W. (2014). Pengaruh 
Partisipasi Pemakai dan Dukungan Manajemen terhadap Kinerja Sistem Informasi Akuntansi pada Bank Umum Pemerintah. Universitas Terbuka. Soegiharto. (2001). Influence Factors Affecting The Performance of Accounting Information Systems. Gajah Mada International Journal of Business, 3(2), 177-202. Retrieved from

https://www.academia.edu/19803755/ The_Influence_of_Information_Syste m_User_Competency_and_The_Quali ty_of_Management_Accounting_Infor mation_Systems_on_User_Satisfactio n. Accessed on March 21, 2020

Sugiyono. (2017). Metode Penelitian Kuantitatif, Kualitatif, dan $R \& D$. Bandung: Alfabeta.

Sujarweni, V. W. (2015). SPSS Untuk Penelitian. Yogyakarta: Pustaka Baru. Supranto, J. (2005). Ekonometrika Buku I.
Jakarta: PT Ghalia Indonesia.

Sutabri, T. (2015). Sistem Informasi Akuntansi. Surakarta: Andi.

Utama, D. G. B. (2014). Faktor Faktor yang Mempengaruhi Kinerja Sistem Informasi Akuntansi pada Lembaga Pengkreditan Desa. Jurnal Akuntansi, 9(3).

Widaninggar, N. (2013). Value Added Implementasi Enterprise Resource Planning (ERP). Jurnal Akuntansi Dan Manajemen, 10(2), 306-317. Retrieved from http://manajemen.upy.ac.id/manajeme n/wp-content/uploads/2016/12/ValueAdded-Implementasi-EnterpriseResource-Planning-ERP.pdf. Accessed on July 8, 2019 Wulandari. (2018). Faktor-faktor yang Mempengaruhi Keberhasilan Implementasi Sistem Informasi Akuntansi. STIE Mandala Jember. 